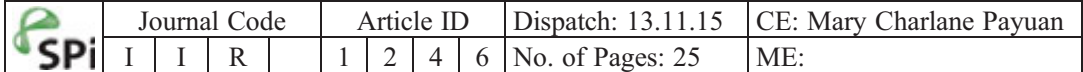

\title{
Studies in Convergence? Post-Crisis Effects on Corporate Rescue and the Influence of Social Policy: The EU and the USA ${ }^{1}$
}

\author{
Jennifer L. L. Gant*
}

Nottingham Trent UniversityNottingham Law School, UK

\begin{abstract}
The financial crisis and the sovereign debt crisis that it precipitated in a number of peripheral EU Member States heralded massive changes in insolvency, corporate rescue and employment protection policies. The US and the EU both suffered greatly in the wake of the crisis, but their recoveries have occurred along very different tracks. The US has managed to regain much of its position in terms of relative growth and the UK has outpaced the recoveries of those European countries that are members of the European Monetary Union. The purpose of this treatise is to explore the context of the 2007-2008 financial crisis in the US and in the EU and its impact on legal reform in corporate rescue and restructuring as well as those aspects of social policy implicated within insolvency systems (notably collective redundancy and transfers of undertakings). It will also consider whether or not the corporate rescue and employee protection systems can be seen to be converging, and whether, in view of the different socio-economic, political and cultural aspects of the US and the EU, such convergence might be beneficial.
\end{abstract}

\section{Introduction}

It is a different world since the beginning of the financial crisis of 2007. Where there was once an emphasis on the protection and creation of workers' rights in many nations, particularly within the European Union, ${ }^{2}$ these are now being tempered by

\footnotetext{
*Email: JenniferL.L.Gant@gmail.com

1. This piece was the recipient of the 2014 inaugural Ian Strang Founders Award sponsored by INSOL International and was presented at the INSOL International Academics Colloquium in San Francisco, California USA on 24 March 2015. The author would
}

like to thank INSOL International for this opportunity and the Ian Strang Award board for the honour of choosing this piece.

2. Hereafter referred to as the "EU". 
pressing financial issues of sovereign debt, weakened national economies and soaring deficits. Not every country experienced the financial crisis in the same way. This is due in part to their position in their economic cycles prior to the crisis, the fundamental strength of national economies preceding the crisis, the effects of membership of the European Monetary Union ${ }^{3}$ and the spending habits of governments and consumers. The United States ${ }^{4}$ and the EU have fared differently, while individual EU Member States provide interesting examples of the diverse range of impact that the financial crisis has had throughout the western world.

The financial crisis had a pervasive impact on the real economy of the EU. ${ }^{5}$ Nearly all high income countries suffered an increase in debt during the recession that followed. One of the fundamental differences between EU and US economies is the fact that although the EU Member States are bound by a common currency, they are not constrained by a common fiscal policy. Thus debt ratios and budget deficits vary significantly across all EU Member States, despite the fiscal restrictions contained in the EU Treaties. ${ }^{6}$ The extent to which the financial crisis affected individual Member States depended on their initial economic and regulatory conditions and vulnerabilities, often associated with the initial and ongoing effects of joining the EMU. ${ }^{7}$

Since the beginning of the financial crisis there have been massive changes in national approaches to the regulation of aspects of national and supranational economies and social policies. This is particularly evident in the changes that have occurred throughout the EU in its reduced emphasis on social protections, in favour instead of a more neo-liberal approach designed to support its weakened economic status. Member State reforms under these revised EU policies as well as the austerity measures required in those States that are party to Memoranda of Understanding $^{8}$ in return for financial support have seen the steady erosion of workers' rights generally, while the "rescue culture"9 has been steadily infused into Member State legal systems. While the presence of good rescue mechanisms may mitigate to some extent the loss of social protection, it is questionable whether or not such reforms are capable of going far enough to protect the most vulnerable of those EU citizens affected by the financial crisis.

The US and the EU are often seen to conflict in their approach to social policy issues, although the US also presents an often emulated rescue regime in Chapter 11 of the US Bankruptcy Code. ${ }^{10}$ Both the EU and the US have been significantly affected by the financial crisis, but the US has been able to recover more quickly

3. Hereafter referred to as the "EMU".

4. Hereafter referred to as the "US".

5. Commonly referred to as PIIGS (Portugal, Italy, Ireland, Greece and Spain); for the purpose of this paper, they will be referred to as the GIIPS.

6. T Grennes, "Diminishing Quality of Fiscal Institutions in the US and the EU" (2013) 33(1) Cato F 91, 101.

7. "Economic Crisis in Europe: Causes, Consequences and Responses" (2009) 7 European Economy - Economic and Financial Affairs 8-10, 20-27.

8. Hereafter referred to as "MoU".
9. An economic policy emphasising the priority of re-
habilitating viable companies in financial distress for
the purposes of preserving their economic value as well
as the livelihood and well being of those dependent
upon an enterprise, including unsecured creditors, em-
ployees, communities and other stakeholders.
10. An Act to Establish a Uniform Law on the Subject of
Bankruptcies enacted by the $95^{\text {th }}$ United States Congress
Pub L 95-598, 92 Stat 2549 of November 6 1978.

Copyright (C) 2015 INSOL International and John Wiley \& Sons, Ltd

Int. Insolv. Rev. (2015) DOI: $10.1002 /$ iir 
and, it could be argued, more effectively than has the EU, although individual EU Member States have varied in their survival and recovery. The question is, then, whether the EU can learn anything from the US handling of the financial crisis, and in particular its approach to social policy and the effectiveness of its corporate rescue regime. Given the shift in economic and social policy within the EU and its effects on the Member States, has there also been some form of convergence the EU and the US as there has been to some extent among the Member States of the EU? The purpose of this treatise is to explore the context of the 2007-2008 financial crisis in the US and in the EU, its impact on legal reform in corporate rescue and restructuring and those aspects of social policy implicated within insolvency systems (notably collective redundancy and transfers of undertakings), whether or not the corporate rescue and employee protection systems can be seen to be converging, in view of the different socio-economic, political and cultural aspects of the US and the EU, such convergence might be beneficial or, indeed, possible.

\section{A. The EU conundrum: social policy and corporate rescue}

Social policy refers to the provision of services, income and protection for vulnerable or unfortunate citizens who are unable to support or protect themselves. The basis for social policies stems from human rights protected by the EU and national court systems and the social ills they are aimed to resolve. Although the background to social policy is universal, the level and form of investment in these matters vary. ${ }^{11}$ Until relatively recently, social policy was viewed as a poor relation in the process of European integration. The Treaty of Rome ${ }^{12}$ merely exhorted the Member States to improve working conditions and standard of living for workers without actually conferring any rights on the workers themselves. The initial view was that economic integration itself would ensure an optimum social system through the removal of obstacles to free movement. The Ohlin ${ }^{13}$ and Spaak ${ }^{14}$ reports upon which the social policy aspects of the Treaty of Rome were based rejected the idea of trying to harmonise social policy within the European Community ${ }^{15}$ because it was thought that as higher costs tend to accompany higher productivity, the differences between countries were not as great as they appeared. ${ }^{16}$

In the early days of the EC, the absence of a clearly identifiable social policy can be explained by the fact that social policy and labour law lay at the heart of the

11. P Kettunen and C Wolff, "Europeanisation through the Back Door: EU Social Policy and the Member States" (2010) 47(5) Politicka misao 144, 146.

12. The Treaty establishing the European Economic Community (EEG) (1957).

13. 'Social Aspects of European Economic Co-Operation: Report by a Group of Experts, Studies and Reports, New Series, No. 46 (Geneva 1956). The findings of the experts were summarised in "Social Aspects of European Economic Co-Operation" (1956) 74(2) Int'l Lab Rev 99.
14. "The Brussels Report on the General Common Market" published by the Information Service High Authority of the European Community for Coal and Steel, Luxembourg June 1956.

15. Hereafter referred to as the "EC".

16. See A Philip, "Social Aspects of European Economic Co-Operation" (1957) 76 Int'l Lab Rev 144 and C Brewster and P Teague, European Community Social Policy and its Impact on the UK (Institute of Personnel Management 1989) 52. 
sovereignty of Member States and was viewed as a means of preserving national integrity and political stability. ${ }^{17}$ If national markets had remained closed and independent, social policy could continue as a domestic concern; however, once the EC had created the Common Market with a common currency, social policy in one country became relevant to other states as it affects the integrity of the currency and competitiveness within the Common Market. ${ }^{18}$ After decades of slow but progressive changes to employment rights and protections within the EU, all Member States are now bound by the EU Charter of Fundamental Rights ${ }^{19}$ and the Social Chapter of the EU Treaty, ${ }^{20}$ with some narrow derogative options. ${ }^{21}$ However, EU social policy remains within the domain of Member States to determine, requiring unanimous decision making in legislative proposals falling under its definition. ${ }^{22}$ As social institutions are deeply embedded in each country's larger societal framework and history, they cannot be easily aligned ${ }^{23}$ as will be seen by the diverse ways in which social policy related directives are implemented in Member States.

The approach to social policy differs significantly from the more closely coordinated action taken the EU in matters of insolvency. The cooperation of European countries in matters of insolvency has a long history. The project has been in progress for over 40 years within the EU, evolving in complexity and increasing in cooperation as the EU has expanded and changed. ${ }^{24}$ The culmination of this cooperation was the EU Insolvency Regulation, ${ }^{25}$ which deals with the coordination of cross-border insolvency between Member States. While this does not implement an EU wide insolvency system, the aims and outcomes of corporate rescue mechanisms throughout the EU do not have the same variance that social policy regulation does. This could be explained by the fact that insolvency, as a corporate law matter, has a more international influence given the globalised marketplace in which most businesses now exist. A closer alignment of insolvency mechanisms is logical, therefore, as it makes cross-border business less complicated. This may also explain the EU approach to a cross-border insolvency regulation, rather than trying to implement an EU wide insolvency system. There is perhaps a more natural tendency to align systems that are forced to interact regularly in the common and international markets. ${ }^{26}$

17. W Streeck, "Neo-Voluntarism: a New European Social Policy Regime?"(1995) 1 ELf 31, 31.

18. D Trubek and L Trubek, "Hard and Soft law in the Construction of Social Europe: the Role of the Open Method of Coordination"'(2005) 11(3) ELF $343,345$.

19. Charter of Fundamental Rights of the European Union OJ 2000/C 364/1 of 18 December 2000. 20. The Treaty on European Union OJ C/191/01 of 29 July 1992 (the Maastricht Treaty).

21. The Treaty of Amsterdam incorporated the provisions of the Social Chapter directly in 1997.

22. N Esenturk, "EU Social Policy: Progressive Development in Legal and Governance Aspects" (2010) UK Social Policy Association <http://www.social-policy.
org.uk/lincoln/Esenturk.pdf $>$ accessed 17 November 2012, 2-3.

23. Kettunen and Wolff (n1 1) 148.

24. P Omar, European Insolvency Law (Ashgate 2004) 49.

25. Council Regulation (EC) No. 1346/2000 of 29 May 2000 on Insolvency Proceedings (OJ 2000/ L160/1) (hereafter referred to as the "EIR").

26. See M Siems, "Shareholder, Creditor and Worker Protection: Time Series Evidence about the Differences between French, German, Indian, UK and US Law" (2012) Centre for Business Research, University of Cambridge, Working Paper No $381<$ http://papers. ssrn.com/sol3/papers.cfm?abstract_id=1329997> accessed September 2013. 
This same idea can explain to a certain extent why it is that Member State employment and labour regulations have not seen the same kind of convergence or direct regulation by the EU. Workers are generally less mobile with the consequence that differences in preferences can lead to differences in labour law systems. Also, the political context of business versus labour is specifically a domestic concern; as such, the conflicting pressure may steer different countries in different directions. $^{27}$ This also offers justification for legislating in this area with directives, which are binding only as to the result to be achieved. There are a number of directives under EU Law that serve to further preserve employment and workers' rights in insolvency situations in relation to collective redundancies, ${ }^{28}$ transfers of undertakings ${ }^{29}$ and state guarantee funds for employee wages and other compensation. ${ }^{30}$ Member States have taken varied approaches to the implementation of these directives ${ }^{31}$ as derogations are available that have been implemented differently among the Member States owing to the endogenous factors of culture, legal tradition and domestic social policy. ${ }^{32}$ While social policy directives and their implementation among Member States provide a minimum level of protection for employees affected by their employer's insolvency, they have not prevented the massive issues of unemployment and precarious job security that has accompanied the financial crisis in the EU.

\section{B. The financial and sovereign debt crisis in the EU}

There has been a marked difference in the effects and responses to the financial crisis between the GIIPS, or peripheral EU Member States and the central core of the north western EU Member States. ${ }^{33}$ The latter of these had been on a campaign of market flexibilisation since the creation of the EMU, while the former countries have tended to lag behind in their social reforms, although most also began from a different point in the modernity of their individual national economies. ${ }^{34}$ While the launching of the Euro was met with hope that it would create a wave of competitive, supply-side reforms across the EU, not every country succeeded in

27. M Siems (n26) 20-21.

28. Council Directive 98/59/EC of 20 July 1998 on the approximation of the laws of the Member States relating to collective redundancies, OJ L 255 provides standards to be used when an employer is contemplating collective dismissals which must be applied in a situation that involves dismissing 20 employees over a period of 90 days or the lesser of $10 \%$ or 30 employees over 30 days.

29. Council Directive 2001/23/EC of 12 March 2001 on the approximation of the laws of the Member States relating to the safeguarding of employees' rights in the event of transfers of undertakings, businesses or parts of undertakings or businesses, OJ L 82-provides for specific protections for employees subject to business transfers requiring the transfer of their employment contracts with continuity of employment, but allows for specific derogations in insolvency situations.
30. Council Directive 80/987/EEC of 20 Octover 1980 on the approximation of the laws of hte Member States relating to the protection of employees in the event of the insolvency of their employer, OJ L 283.

31. Ius Laboris, Collective Redundancy Guide (2009) $<$ http://www.iuslaboris.com/files/documents/Public \%20Files/Publications/2009_Publications/collectiveredundancies-guide.pdf $>$ first accessed 2013.

32. Ius Laboris, Guide on Transfer of Undertakings, available from http://www.iuslaboris.com/files/documents/Public\%20Files/Publications/2008_Publications/transfers-of-undertaking.pdf first accessed 2012. 33. France, Germany and the United Kingdom.

34. "Economic Crisis in Europe: Causes, Consequences and Responses" (2009) 7 European Economy - Economic and Financial Affairs 8-10, 20-22. 
implementing long-lasting reforms that would help them to cope better with the discipline of living within a single currency. Fiscal convergence criteria for the Euro chiefly had to do with controlling inflation and government debt. ${ }^{35}$ The GIIPS countries made strenuous efforts to qualify for the Euro by reducing public spending and holding down wages and other costs, but these provisions were often relaxed once they were admitted to the EMU. ${ }^{36}$ In addition, the fact that while they are joined within a common monetary union, EU Member States are not joined under a single fiscal policy exerting stewardship over their economies has led to diverse approaches in dealing with the economic problems caused by the crisis. 37

The issues dividing the GIIPS and core EU countries in the effects that the financial crisis has had on their individual economies can be traced in part back to the creation of the EMU. The decision to enter into a common currency, while in principle strictly financial, had huge political and social implications as it provided an unprecedented connection between the economic destinies of European nations who had relinquished one of the most fundamental functions of sovereignty: the control of their own currency and monetary policy. ${ }^{38}$ While the Euro provides considerable economic and political benefits to core countries by making it impossible to undercut exports with currency depreciation, many GIIPS countries have lost a considerable portion of their market share that had once been greater when the lower cost of production systems allowed for lower prices in export. This led to trade deficits that have contributed in part to the sovereign debt crisis, ${ }^{39}$ which is not, therefore, merely a debt crisis, but a competitiveness and growth crisis resulting from structural imbalances within the EMU. ${ }^{40}$

Because of being a part of the EMU, the GIIPS countries could not address their mounting problems by devaluing their currency or through inflation. ${ }^{41}$ With no recourse to these fiscal policy options, the Euro became a straightjacket for those members struggling with sovereign debt and to comply with EU fiscal requirements. $^{42}$ The resulting crisis has led to the enactment of austerity measures carried out by all of the GIIPS countries, in particular those subject to so-called Memoranda of Understanding (MoUs), a new instrument that departs from any EU instruments agreed to the open method of coordination or other hard legislation. These MoUs contain the conditions of the financial support of the European Commission, European Central Bank and International Monetary Fund. ${ }^{43}$

\footnotetext{
35. JA Caporaso and Min-Hyung Kim, "The Maastricht Treaty at Twenty: A Greco-European Tragedy?" (2012) 34(7) Eur Integration 769, 778.

36. "The European Central Bank: Ten Years on, Beware the Porcine Plot" (2008) June $5^{\text {th }}$ The Economist <http://www.economist.com/node/11496844> accessed 14 August 2014.

37. J Gokhale and E Partin, "Europe and the US: On the Fiscal Brink?" (2013) 33(2) Cato f 193, 193.

38. F Pavoncello, "One for All, All for One: The Euro in Crisis" (2011) May/June World Affairs 59, 62.

39. C Hadjmichalis, "Uneven Geographical Development and Socio Spatial Justice and Solidarity:
}

European Regions after the 2009 Financial Crisis" (2011) 18 Eur Urban and Regional Studies 254, 259-264. 40. B Moro, "Lessons from the European Economic and Financial Great Crisis: A Survey" (2014) 34 Eur f Political Economy S9-S24,

41. K Armingeou and L Baccaro, "Political Economy of the Sovereign Debt Crisis: the Limits of Internal Devaluation" (2012) 41(3) ILf 254, 255-256 \& 263-265. 42. F Pavoncello (n38) 65.

43. The "troika". 
MoUs have essentially replaced the EU recommendations that generally emerge through the economic policy coordination process. ${ }^{44}$ They are essentially reactive in nature, as a means of saving ailing economies and protecting the EU from the effects of sovereign debt default. ${ }^{45}$ The introduction of austerity measures has forced the GIIPS countries to begin a process of forced convergence, bringing them into closer alignment with the UK and Germany, although France continues to maintain its own unique social contract. The effects of the austerity measures taken under the MoUs, the stagnation, slow recovery and high national debts have resulted in a spectrum of reforms in economic and social policy areas, including insolvency, corporate rescue and the treatment of workers affected by an employer's insolvency. The same has not occurred in the US, but it does provide an interesting model of comparison in the context of the crisis and responses to it.

\section{Born in the USA: American social policy and chapter 11}

Before examining social and economic policy within the US, certain constitutional and governmental structures must be understood. Like the EU under the Treaties, the federal government of the US is limited by certain enumerated powers listed in the Constitution. The Constitution enshrines the concept of federalism by espousing certain political and social values that promote the diffusion of power that reduces the perceived risk of tyrannical federal control. ${ }^{46}$ The importance of federalism is a fundamental characteristic of the US political system and has given the US Constitution an extraordinarily high status in the hierarchy of legal institutions, particularly when compared to other constitutional democracies or to the new breed of constitutional federalism characterised by the EU political structure and institutions.

The enumerated powers of the Constitution include seven original articles and twenty seven amendments. Bankruptcy is covered expressly under the Constitution as a power of the federal government; ${ }^{47}$ however, contract law and other domestic state concerns are not. While certain rights are now guaranteed for employees in the US, these rights do not derive from any specific constitutional article or amendment implementing social policy objectives on a federal level. Rather, they derive from various articles and amendments to the Constitution that has been used to justify their existence. Notably, employee rights such as minimum wage, working hours, health and safety, equal pay and even civil rights issues such as affirmative action ${ }^{48}$ have been justified as being covered by the Commerce

44. K A Armstrong, "New Governance and EU Fiscal Discipline" (2013) 38(5) E L Rev 601, 606-607.

45. F Pavoncello (n38) 68 and B Eichengreen, "The Euro's Never-Ending Crisis" (2011) March Current History 91.

46. MH Redish, "Doing it with Mirrors: New Yorkv. US and Constitutional Limitations on Federal Power to Require State Legislation" (1993) 21 Hastings Const L Q 593, 604.
47. Article 1 Section 8 Clause 4 states that Congresses enumerated powers include the power to establish a uniform rule of naturalisation and uniform laws on the subject of bankruptcies throughout the US.

48. Although the groundwork for these were laid by the $13^{\text {th }}$ amendment abolishing slavery, the $15^{\text {th }}$ amendment prohibiting discrimination in the right to vote based on race and the $15^{\text {th }}$ amendment giving women the right to vote laid the groundwork for these laws. 
Clause ${ }^{49}$ which allows the federal government to regulate business conducted across state lines. There is also a "necessary and proper" clause providing Congress with a significant degree of flexibility in the invocation of its enumerated powers, although this flexibility has been continuously mitigated by a focus on the limitations on the federal government set out with some specificity in the Constitution. ${ }^{50}$ The context of US social policy differs significantly from EU social policy that figures quite prominently in most Member States through the implementation of social policy directives having legal basis set out in the Social Chapter of the EU Treaty, unlike the lack of specific social policy considerations in the US Constitution.

\section{American social policy, employment and labour regulation}

The American labour and employment system is characterised by the concept of "at-will" employment in which employers possessed the legal authority to determine unilaterally the terms and conditions of an employment relationship. This imbalance between employer and employee is tempered to some extent by the benefits of union membership through which employers and unions can set the terms and conditions of employment. However the union sector comprises only about $11.3 \%$ of the current labour market. ${ }^{51}$ Since peaking at $34.7 \%$ in 1954 , the decline has been attributed to a variety of factors, such as the globalised economy that has reduced union power to create and keep a monopoly within product markets; changes in the composition of the workforce; the increase in contingent work instead of a concentrated core worker system characterised by long-term employment relationships; deficiency of union regulation; employer opposition to unions; and the nature of American unionism and its roots in pragmatism rather than politics. Unionism never rose to the heights that it achieved in other industrialised countries, which might be traced in part to the individualistic character of the American psyche. ${ }^{52}$

While, broadly speaking, the "at-will" rule is still in place, a number of statutes have also been enacted that place limitations on this doctrine. In the mid 1960s, union regulation ${ }^{53}$ and minimum wage and working time regulations ${ }^{54}$ were joined by a number of anti-discrimination and other statutes intended to set minimum workplace requirements. ${ }^{55}$ Prior to the millennium, there were also a number of judicially led limitations placed on the "at-will" rule in several American

49. Article 1 Section 8 of the Preamble to the US Constitution

50. MH Redish (n46) 604.

51. Bureau of Labor Statistics Economic News Release: Union Members Summary (January 2014) available from http://www.bls.gov/news.release/union2. nr0.htm accessed 29 October 2014.

52. SF Befort, "Labour and Employment Law at the Millennium: a Historical Review and Critical Assessment" (2001) 43 B C L Rev 460, 355-375.
53. Notably the National Labour Relations Act 1935, which obligated employers to negotiate with freely selected union representatives of their employees.

54. The Fair Labour Standards Act 29 U.S.C ss201209 (1994) mandating the forty hour work week and the minimum wage.

55. See for example The Civil Rights Act 1964, Americans with Disabilities Act 1990, Genetic Information and Non-Discrimination Act 2008. 
states. Most jurisdictions permit a public policy tort action that allows an employee to claim that a dismissal or discharge decision offends public policy, generally barring employers from dismissing employees for refusing to perform an unlawful act, exercising statutory rights or who report an employer's unlawful conduct. ${ }^{56}$ Contract claims are also generally an exception to the "at-will" rule because of the implication of certain contractual obligations such as job security or disciplinary procedures, whether from an oral covenant or in an employee handbook where such agreements are in place. Further, some jurisdictional courts have implied covenants of good faith and fair dealing, requiring each party to refrain from acting in bad faith in a way that frustrates the others' expectations of the employment relationship. $^{57}$

The reasons for the introduction of legislation limiting the "at-will" doctrine have been placed at the feet of the changing nature of the workplace in which the doctrine is at odds with the realities of contemporary employment relationships. Also, there was a recognised need to implement some labour protection because of the significant decline in union membership and power. These contemporary employment relationships are characterised by increasingly large corporate employers as well as specialised job functions that have made mobility within the labour market less realistic. In addition, advances in trade and technology have further tipped the balance of power toward employers, particularly in view of the need for employers to compete on the world market, leading to a "race to the bottom" of employment rights. The lack of any regime for protecting employees from unfair dismissals further exacerbates this problem as workers are not protected from whimsical dismissal unless it is based on the protected characteristics of discrimination legislation or if it occurs within one of those jurisdictions where the courts have limited the application of the "at-will" doctrine. 58

There are limited protections available to employees affected by an employer's insolvency. The Worker Adjustment and Retraining Notification Act, ${ }^{59}$ essentially a statute requiring advance notice if collective redundancies were envisaged, was passed to mitigate some of the issues surrounding large scale bankruptcies. This act does not require consultation as does the EU's Collective Redundancies Directive, merely 60 days advance notice in employers having over 100 employees, although it excludes several categories of workers, including those engaging in collective action at the time of the notice. ${ }^{60}$

The labour side of labour and employment law in the USA is predicated on the belief that employees have the right to organise, to bargain collectively and to engage in concerted activities for mutual aid and protection as set out in the National

56. Known as "whistle-blowing" in the UK which as a reason for discharge is now prohibited in a number of American states.

57. S F Befort (n52) 378-383.

58. Ibid, 385-393.

59. An Act to require advance notification of plant closings and mass layoffs, and for other purposes (the
"WARN" Act) enacted by the $100^{\text {th }}$ United States Congress, Pub. L. 100-379 102 Stat 890.

60. Council Directive 98/59/EG of 20 July 1998 on the approximation of the laws of the Member States relating to collective redundancies. 
Labour Relations Act. ${ }^{61}$ It has also been recognised that employees have the right not to engage in any of these collective activities. This area of American social policy with regard to employees is relatively coherent and efficient. However, the employment side not governed by union regulation is not so structured. The aims of employment regulation have no philosophical basis or foundational principal, unlike all of the employment protection regimes throughout the EU, although individual Member States vary on what those foundational principals are. Further, there are significant jurisdictional issues when it comes to bringing claims challenging an employee's discharge, including the number of claims available and the number of forums within which they might be heard. Those employees protected by collective agreements may have the opportunity of bringing a civil claim in addition to a claim under labour arbitration, thus allowing "two bites of the apple". The confusion in the system causes great expense and lawsuits often take years to resolve. This precludes the less wealthy from trying to attain justice in any event.

While a Model Employment Termination Act was introduced in 1991 that governs issues of employment security and unfair discharges, it has yet to be adopted by any state apart from Delaware. ${ }^{62}$ Thus it can be questioned whether the current state of affairs in US labour and employment law is an efficient means of attaining justice for employees, employers or as a legal regime that that fits within a modern economy. This is not helped by the lack of federal power to control social policy in this area in any fundamental way because of the fact that contract law, of which employment law is a subset, is governed by individual state legal systems. Given the financial crisis and the restructurings ensuing from it, the treatment of employees in corporate rescue situations is also of great interest.

\section{Chapter 11 and employee entitlements}

Chapter 11 provides for the US' upstream corporate rescue procedure and was first introduced in the Bankruptcy Reform Act. Its aim was to push managers of financially troubled firms toward reorganisation rather than succumbing to liquidation. The United States Congress believed that assets would be better utilised in the industry with which they were associated, rather than being scrapped and sold off for parts to random buyers. ${ }^{63}$ Congress also stated that it is more economically efficient to reorganise than to liquidate because it preserves jobs and assets. ${ }^{64}$ The Bankruptcy Reform Act recognised the costs on various stakeholders to a bankrupt company, including creditors, employees, suppliers, customers and communities and concluded that an alternative to a court supervised reorganisation was required to protect businesses from ultimate failure, thereby protecting the associated stakeholders and

61. An act to diminish the causes of labour disputes burdening or obstructing interstate and foreign commerce, to create a National Labor Relations Board, and for other purposes (the "NLRA" or Wagner Act) enacted by the $74^{\text {th }}$ United States Congress on July 6 1935, Pub. L. 74-198, 49 Stat. 449.
62. S F Befort (n52) 396-424.

63. M Bradley and M Rosenzweig, "The Untenable Case for Chapter 11" (1992) 101(5) Yale L J 1043, 1043-1044.

64. See HR Rep No 595, $95^{\text {th }}$ Cong $1^{\text {st }}$ Sess. 220 (1977) 
enhancing social welfare. Chapter 11 was one of the first truly "up-stream" rescue procedures that could be available to both insolvent businesses and those to who could merely see financial troubles ahead. It is also designed with a strong presumption toward retaining the management of the company ${ }^{65}$ throughout the reorganisation process. ${ }^{66}$

While there are certain employee rights available under Chapter 11, these do not always adequately protect employees who might be subject to drastic reductions in the workforce, pensions and other employee benefits. As these are not protected in any way by statute, and in the absence of any protection from collective agreements, employees may get notification of redundancies but will essentially just have to suffer the loss of their jobs and associated benefits. These drastic reductions often occur at the beginning of a reorganisation process, which is then sometimes followed by the payment of massive retention bonuses to upper management in order to keep them "on the job."67 Thus, there is often a great divide between the treatment of managers as opposed to workers and employees in the context of Chapter 11 restructurings. ${ }^{68}$ In addition, collective agreements and employment contracts can be summarily terminated under the Bankruptcy Code. 69 The persistence of the "at-will" doctrine means that employees in these situations will have recourse to legal protection in only limited circumstances.

The argument for protecting employees with some priority in insolvency or rescue situations is derived from a number of justifications. The purpose of Chapter 11 as a reorganisation procedure indicates the managers' hope that the business will continue and by remaining with that employer, an employee will have a number of future constituent interests dependent upon the continuation of the business. These include wages, benefits and even future employment. Also, an employee's wages represent a large part of that person's wealth; they do not assume the risk of their employer's default as a creditor might. From a business protection point of view, the priority of employee claims may prevent valuable employees from seeking work elsewhere while a reorganisation is taking place. ${ }^{70}$ Employee claims that occur prior to the petition for Chapter 11 may be protected if a relevant collective agreement is in place, providing a contractual basis for a claim, which if assumed by the debtor will remain in force, requiring the debtor to cure any defaults occurring pre-petition. However, given the extraordinarily small percentage of employees who are engaged in union activities today, it is more likely that the

65. Also known as "debtor in possession". 66. M Bradley and M Rosenzweig (n63) 1043-1044. 67. See for example Re Eastman Kodak Co. Et al, Voluntary Petition for Chapter 11 Bankruptcy, Case No 1210202, So, Dist. NY (2012) available from http:// bankrupt.com/misc/Kodak_StipSpectra073013.pdf first accessed 30 October 2014 .

68. J Berry, "Different Playing Fields: What Affect Does Chapter 11 Bankruptcy Have on Employees of the Debtor and Why do, These Affects Drive Companies to Bankruptcy?" (2012) Social Sciences Research
Network <http://papers.ssrn.com/sol3/papers.cfm? abstract_id $=2139062>$ first accessed 30 October 2014.

69. PA Susser, AM Wever and SJ Friedman, "Employment and Employee Benefits in the US: Overview" (2014) Practical Law Multi Jurisdictional Guide on Employment and Employee Benefits <http://global. practicallaw.com/1-503-3486 $>$ first accessed 28 October 2014

70. D R Korobkin, "Employee Interests in Bankruptcy" (1996) 4 Am Bankr Inst L Rev 5, 6 
employment will be "at-will" and subject to whatever provides the greatest benefit for the employer company's circumstances at the time. ${ }^{71}$

Employee claims occurring prior to the petition for Chapter 11 rank fourth in priority under the US Bankruptcy Code. However, these are limited to claims of direct compensation in wages, salaries and commissions that have been earned at the time of the petition but not yet paid in the 180 days prior to the filing for bankruptcy and are limited in the amount claimable. This also applies to pension and welfare benefit claims arising under a pre-established plan. ${ }^{72}$ These rank equally to and combine under the limitations applied to wages and salaries. While true that these claims carry priority, this is only after administrative expenses and secured claims have been paid. Certain damages claims might also rank with priority, although this is only if the relevant employment contracts have been assumed, in the absence of which the debtor will have no obligation to pay damages immediately upon breach. ${ }^{73}$

Following the petition for bankruptcy, those employees that have been assumed by the debtor are assured of being paid for services rendered during the reorganisation. These rank as an administrative expense and are given first priority, although it is rare that such a claim will arise as a debtor will be sure to continue to pay such administrative debts as they fall due or risk not completing reorganisation. ${ }^{74}$ In any event, while priority exists, it falls short of the priority given to employees in similar situations in EU countries as employees with pre-petition claims essentially rank equally with unsecured creditors and are limited in time and amount claimable.

In terms of the employment protection regulation available to employees during the insolvency of their employer, the "at-will" doctrine continues to apply. An employee does not have the right to be transferred with a business to which he is associated and if he is, there is no continuity of employment between the previous employer and the new one. Essentially, this relies on basic laws of contract that once governed the whole of employment law in the United Kingdom, although this is now mitigated by employment protection regulation aimed at correcting the power imbalance in the employment relationship. There are no statutory notice periods, requirements for severance or redundancy pay, or procedural requirements for dismissal. For any of these to apply, they would have to be included in a collective agreement or perhaps an employee handbook. Employers can lay-off employees for any reason that does not violate anti-discrimination statutes or that constitute an act of bad faith. The only mitigation here is the WARN Act, which requires notification of a mass layoff or plant closure under specific

71. Ibid., 6-12.

72. Pensions refers only to retirement income while welfare benefits refer to medical, health, accident, disability or death benefits, severance pay, training, apprenticeship programmes, day care and prepaid legal services. 73. PM Secunda, "An Analysis of the Treatment of Employee Pension and Wage Claims in Insolvency and Under Guarantee Schemes in OECD Countries: Comparative Law Lessons for Detroit and the US" (2014) XLI Fordham Urban Law Fournal 867, 898 and DR Korobkin (n70) 8-9.

74. DR Korobkin (n70) 14-15. 
circumstances as described above. ${ }^{75}$ The crisis has done little to inspire reforms in the treatment of employees affected by an employer's insolvency in the US, although the EU and Member States have proceeded with reforms in this area in a number of ways, both positive and negative.

\section{Corporate rescue and worker protection in the context of crisis in the EU}

At the start of the crisis, public authorities and national legislatures took a range of measures to boost enterprise flexibility that included amendments to national labour law. While some countries proceeded with flexibilising labour regulation with a view toward its modernisation, a number of countries were forced into this position because of austerity measures contained in MoUs that inevitably required substantial changes to labour as well as banking regulation and in some cases corporate rescue systems in order to reduce the risks associated with their perceived economically ineffective regimes. ${ }^{76}$ Workers' rights have now been reduced throughout the EU in a number of areas, including those areas associated with insolvency and financial difficulty such as collective redundancies, hours of work and general revisions to rules on employment protection. ${ }^{77}$ It is interesting to note, however, that few of these reforms have been instigated through normal legislative channels, but under the reactive MoUs and through political pressure.

There are a number of responses taken to the financial and debt crisis that vary from Member State to Member State in terms of both supporting the rescue culture and reforming the labour market. There were a number of reforms to corporate rescue regimes throughout the $\mathrm{EU}$ in the early $21^{\text {st }}$ century, and then just following the financial crisis, with the aim of supporting a rescue culture, although a number of jurisdictions have found themselves at different depths along the stream of rehabilitation and recovery. These regimes have operated with varied success as an effective embankment for the protection of failing businesses and the social and economic welfare associated with them in terms of the range of employee entitlements available under corporate rescue procedures and those other legislative factors that provide protection from within labour and employment law. These varied responses are indicative of the differing context in which domestic social policies have evolved and may also show how difficult it may be to force further alignment to achieve better cross-border cooperation.

\section{Germany}

Germany held a very different position within the EU than any of the Member States at the time that the Euro was adopted. European integration has benefitted

75. PA Susser (n69).

76. S Clauwaert and I Schomann, "The Crisis and National Labour Law Reforms" (2012) Working Paper 2012.04 European Trade Union Institute 5-6.

77. D Tajgman and others, "Rights at Work in Times of Crisis: Trends at the Country Level in
Terms of Compliance with International Labour Standards" (2011) International Labour Office Employment Sector Employment Working Paper No. $101,1-2,5-6$. 
Germany and has effectively increased its power. However, it is generally at odds with other Member States in terms of its fiscal and economic policy preferences to stimulate growth. German competition in the EU market is rooted in the suppression of wage increases and to a rise in more precarious employment conditions, a situation that is now evident in the austerity being applied in the GIIPS countries. In terms of its social policy regarding employment protection, there were a number of changes to German welfare in the early 2000s. Germany now has a growing number of young employees working for low pay often without benefits. Its rules on maternity and support for parents effectively discourages many qualified working women from pursuing successful careers after becoming mothers as the conditions are not conducive to a reasonable work-life balance. ${ }^{78}$ Following the financial crisis, the Kurzarbeit ${ }^{79}$ was introduced in which the state paid up to $70 \%$ of a person's salary up to a cap, workers took a cut in hours and pay while in return the employer agreed not to lay off the worker. This short-time working scheme kept German employment figures inflated in contrast to the falling levels of employment elsewhere in the EU. It is believed, however, that this scheme allowed many businesses to survive the sharp decline in orders because of the collapse in international trade in 2009 and to then expand capacity quite quickly during the rebound period of 2010 and $2011 .^{80}$

Germany's insolvency regime has not historically prioritised corporate rescue over liquidation and is comprised of a unitary insolvency proceeding that may have any number of outcomes, including the rescue of the company. There is no normative hierarchy of outcomes for an insolvency situation. ${ }^{81}$ Following the financial crisis there have been reforms to German insolvency law in the Act for the Further Facilitation of the Restructuring of Companies, ${ }^{82}$ which became effective in 2012. This Act has provided greater scope and motivation for restructuring or rescuing a company that the previous unitary procedure did not envisage. It has also introduced protective shield proceedings, ${ }^{83}$ which is a pre-insolvency option that allows a company to develop a restructuring plan as a debtor in possession. ${ }^{84}$ The German insolvency system does not provide any preferences or priorities for wage claims or pensions, although there is a wage guarantee fund sourced by employer premiums and available for the last three months of wages, ${ }^{85}$ which is pursuant to the EU Directive requiring such a guarantee fund to be implemented.

In terms of those EU Directives that aim to protect employee job security during the financial trouble of the employer, Germany applies its transfer of undertakings

78. C Lemke, "Challenging the Ever Closer Union: Political Consequences of the Eurozone Crisis" (2014) 36(1) American Foreign Policy Interests: The Journal of the $\mathrm{Na}$ tional Committee on American Foreign Policy 18, 21.

79. "Short time working".

80. M Hallerberg, "Challenges for the German Welfare State Before and After the Global Financial Crisis" (2013) 33(2) Cato 7 263, 265-266.

81. M Balz, "Market Conformity of Insolvency Proceedings: Policy Issues of the German Insolvency Law" (1997) 23 Brookf Int'l L 167, 172.
82. Gesetz zur weiteren Erleichterung derSanierung von Unternehmen (ESUG, Act Serving the Further Facilitation of the Reorganization of Enterprises) XVII/220, C078.

83. Das Schutzschirmverfahren nach $\S 270 b$ InsO. 84. G Streit and F Burk, "Restructuring and insolvency in Germany: Overview" (2014) Practical Law Multi Jurisdictional Guide 2014/15 Restructuring and Insolvency <http://uk.practicallaw.com/2-501-6976> first accessed 29 October 2014.

85. PM Secunda (n73) 957. 
rules even to those transfers occurring out of insolvency situations with a view to liquidation. There is no entitlement to redundancy pay unless it is provided for in a Social Plan with a works council, which most companies have by default. Its collective redundancy regime applies if an employer intends to make $10 \%$ or more than 25 employees redundant over a 30-day period. Consultation obligations are with works councils in the absence of which there is no obligation to consult at all. These provisions are quite close to the minimum requirements provided for in the Directive.

\section{France}

The French economy was not as severely compromised by the financial crisis as were the UK and Germany. This has been in part attributed to the way in which France internationalised its banking sector with what has been viewed as a more diverse approach with a combination of retail investment as well as corporate lending and investment banking, the latter two being the cause of much of the banking turmoil that caused the crisis. Although French banks were still heavily engaged in market-based banking, they were far smaller investors in toxic assets and other high risk activities. ${ }^{86}$ Throughout the crisis, soft forms of protectionism and limited foreign penetration remained features of the French financial sector while there was only an initial and temporary upswing of intervention as a result of the crisis. ${ }^{87}$ In addition, while the rest of the EU has continually reduced employment entitlements, France has introduced additional protections and assistance for their unemployed $^{88}$ and has maintained the highest level of protection for temporary workers, despite an apparent need to deregulate temporary work to increase flexibility in the labour market to help reduce unemployment rates like the rest of the EU. ${ }^{89}$ France has not followed the same harsh prescriptions for cutting public expenditure to stimulate growth, preferring to protect its social welfare over reducing budget deficits. ${ }^{90}$ In addition, its corporate rescue regime has been well developed for decades and receives regular attention in reform and adjustment.

France might be considered the inventor of the concept of corporate rescue, beginning in 1967 even prior to the legendary Chapter 11 procedure that many systems now try to emulate, although these first procedures were court led unlike Chapter 11. There are a number of up-stream options that allow ever greater opportunity to intervene early in the period when a business is in financial distress. These procedures have been frequently amended during the period of the financial crisis up to as recently as 2014 when a French style of pre-pack was introduced in the sauvegarde financière accélérée. ${ }^{91}$ The French system appears to have the most

86. D Howarth, "France and the International Financial Crisis: The Legacy of State Led Finance" (2013) 26(3) Governance: An International Fournal of Policy, Administration, and Institutions 369, 374 \& 377-382.

87. Ibid., 374 \& 389.

88. D Clegg, "Labour Market Policy in the Crisis: the UK in Comparative Perspective" (2010) Volume 18 Number 1 The Policy Press 5-17, 9.
89. T Vlandas, "The Politics of Temporary Work Deregulation in Europe: Solving the French Puzzle" (2013) Volume 41 Politics \& Society 425-460, 426-417. 90. C Lemke (n78) 21.

91. The "accelerated financial preservation"; P Omar, "A Reform in Search of a Purpose: French Insolvency Law Changes (Again!)" (2014) 23 International Insolvency Review 201, at 203, and 206-208. 
advanced, up-stream, pre-insolvency procedures available, perhaps throughout the whole of the EU. While the frequency of reform in France is great and perhaps, because of that fact, confusing, it also shows a willingness to change with the time in such a way as to keep improving the effectiveness of corporate rescue processes. France's inherent concern for its workers is also supported by the constant improvement of corporate rescue as this inevitably assists in maintaining a higher level of job security. For example, its transfer of undertakings rules apply to all business transfers regardless of the circumstances.

In terms of the employee position in insolvency, employees enjoy a general lien over the employer's property which stands as a guarantee for six months worth of wages and compensation in place of wages, although the lien does not enjoy a high rank in the order of priority. Employees also have access to a guarantee fund for limited compensation where funds are not readily available to pay employee claims. ${ }^{92}$ Employees enjoy a super priority for a limited part of their claim that ranks above all other claims, including those of secured creditors and also affords employees the facility to avoid the disruption and delay of the proceedings so that they can be paid quickly. In the event that redundancies are envisaged, an employee safeguard plan must be put in place that serves to ensure everything has been done to prevent the loss of jobs, further indicating the favouritism enjoyed by employees in France.

In May 2013 France passed a Job Security Bill that introduced a number of reforms to their labour code relating to the rules governing collective redundancies, some affording additional protections to employees. It adopted a law specifying that in the event that collective redundancies result in the offer of a new post abroad, remuneration must be equivalent to that paid in France. Further, the Court of Cassation ruled that contracts terminated by mutual consent for economic reasons in the context of a workforce reduction should also be counted within the number of intended redundancies, thus counting toward the thresholds of collective redundancies, which may then indicate the requirement for an employment safeguard plan to be put in place. Termination by mutual agreement can therefore not be used to circumvent the protections in place for employees subject to redundancy. ${ }^{93}$

The new legislation also affords employers a greater choice as to the procedure they follow when considering collective redundancies in a company of more than 50 employees considering the dismissal of more than 10 within 30 days, triggering a job protection plan. This process was previously quite strict and required timeconsuming and complicated information and consultation exercises with Works Councils. Employers are now able to negotiate an agreement with a relevant trade union or to unilaterally implement a "social plan", which allows employers to depart significantly from standard requirements governing the number of meetings

92. Fund available from the Association pour la Gestion $d u$ Régime d'Assurance des Créances des Salariés (the "AGS"). 93. A Muller, "Employment Protection Legislation Tested by the Economic Crisis: A Global Review of the Regulation of Collective dismissals for Economic Reasons" (2011) International Labour Office, Dialogue in Brief No. 3, 8. 
with employee representatives, timetables for dismissals and selection criteria with the aim of speeding up the collective consultation process. Work councils will also be deemed to have been consulted even if it fails to respond within a now closed timeline. Employers are also now permitted to enter into agreements with trade unions under which employees agree to detrimental changes to their terms and conditions in return for a commitment by the employer not to implement any redundancies during the term of the agreement. ${ }^{94}$ Thus, while France has maintained a relatively high protective stance, it has also given employers a bit more flexibility in dealing with their workforce in times of financial difficulty.

\section{United Kingdom}

While the UK experienced a sudden economic shock in terms of bankruptcies, decrease in consumer demand, drops in gross domestic product growth and an increase in unemployment, it differs from the rest of the EU in several significant ways. It is not part of the EMU; it follows a liberal approach to the economy and a light touch to any kind of interventionist regulation, ${ }^{95}$ which was only enhanced through deregulation as a result of the economic crisis; and its financial structure is highly internationalised. As a result of this latter characteristic, it was one of the first EU countries to be heavily hit by the global crisis because of its strong ties with the financial sector of the US. ${ }^{96}$

In terms of social and unemployment problems caused by the financial crisis, Britain took a distinctly laissez-faire approach and has been unwilling to improve, even temporarily, the already limited support provided in unemployment. It has, in fact, further eroded unemployment benefits and continued to make it more difficult for the more vulnerable members of society, while also trying to encourage as many citizens to return to work. Unfortunately, this latter aim has tended to hit those who are out of work not for any lack of ambition, but because they are unable or incapable of working. Thus, the UK's approach to tackling the crisis has been characterised mostly by tax cuts in an attempt to boost economic activity, while little has been done to address those who are becoming unemployed, differing significantly in approach to the rest of Western Europe. ${ }^{97}$ In addition, the UK has proceeded to deregulate the labour market in a number of areas, including discrimination and equality. It has repealed provisions in the Equality Act 2010

94. J-F Gerard, "International Labour Law Bulletin" Freshfields Bruckhaus Deringer Summer 2013 available from http://www.freshfields.com/ uploadedFiles/SiteWide/Knowledge/36343_FINAL $\% 20$ PDF.pdf first accessed 26 September 2014 and JM Sainsard and C Noblet, "France Introduces Radical Labour Market Reforms" Squire and Sanders, available from and http://www.squiresanders.com/files/ Publication/5fdc90a3-cld2-4c6a-b7 ldab4fc7429426/Presentation/PublicationAttachment/ Ofbce787-35f0-4c05-becd-b2a7e4620235/France-Introduces-Radical-Labour-Market-Reforms-Newsletter. pdf, first accessed 26 September 2014.
95. I MacNeil, "The Trajectory of Regulatory Reform in the UK in the Wake of the Financial Crisis" (2010) 11 Eur Business Organisation L Rev 483, 484.

96. H Chung and S Thewissen, "Falling Back on Old Habits? A Comparison of the Social and Unemployment Crisis Reactive Policy Strategies in Germany, the UK and Sweden" (2011) 45(4) Social Policy \& Administration 354,358 \& 362.

97. B Vis, K van Kersbergen and T Hylands, "To What Extent Did the Financial Crisis Intensify the Pressure to Reform the Welfare State?" (2011) 45(4) Social Policy \& Administration 338-353, 347. 
relating to combined protective characteristics and third party harassment on the grounds that they are perceived as burdens on business. The duty on public authorities to have regard to the need to reduce socio-economic inequalities has been repealed (although it also never entered into force) and the duty on large employers to publish details of the gender pay gap is not being implemented. ${ }^{98}$ It did, however, initiate measures in response to rising unemployment amounting to incentives for employers to hire long term unemployed and funding programmes aimed at getting the unemployed back to work. ${ }^{99}$

The most significant reforms to insolvency law in the United Kingdom in the most recent past occurred just after the turn of the millennium and modified the Insolvency Act 1986 by replacing certain of its provisions with new sections and schedules aimed at improving rescue procedures in terms of efficiency, benefit and practical use. ${ }^{100}$ The revised administration procedure has had arguably the most significant effect on the UK rescue culture as it went further to protect unsecured creditors and was implemented despite the resistance of banks, financial institutions and other primary lenders who had benefitted from the exclusive control that administrative receivership had allowed. ${ }^{101}$ Administration presents three hierarchical objectives with a bias toward rescuing the company as a going concern. ${ }^{102}$ Administration has been supplemented with a non-statutory practice of pre-packs that offer a pre-insolvency type of mechanism that functions on the premise of a pre-packaged sale by an administrator on terms that have been agreed before the administration is commenced, but that is carried out shortly after the appointment of an administrator. ${ }^{103}$ The company voluntary arrangement ${ }^{104}$ and scheme of arrangement ${ }^{105}$ provide two other upstream mechanisms for agreeing to compositions with creditors and debt restructuring. Thus there are a number of options for up-stream and rescue procedures in the UK, providing a means of preserving business and, by association, employment.

The Enterprise and Regulatory Reform Act of $2013^{106}$ introduced reforms aimed at reducing legislative burdens in a number of areas, including employment and insolvency law. In addition, more recent reforms have been introduced in relation to the regulation of insolvency practitioners, ${ }^{107}$ and the deregulation of certain areas of employment and labour law, ${ }^{108}$ although not all of the provisions under these new acts are as yet in force. The impact of these reforms demonstrates

98. B Hepple, "Back to the Future: Employment Law under the Coalition Government" (2013) 42(3) ILf 223, 207

99. H Chung and S Thewissen (n96) 363.

100. Enterprise Act 2002 c.40.

101. The Enterprise Act 2002 curtailed the availability of administrative receivership, while retaining some significant carve-outs. It could be initiated by a floating charge holder holding security over all or most of the company's assets through which it could appoint an administrative receiver to act on their behalf to exercise their security rights, putting them in control of the company assets and generally leading to liquidation and low to no returns for other creditors.
102. P Omar and JLL Gant, "Corporate Rescue in the UK: Ten Years after the Enterprise Act 2002 Reforms" (2014) (forthcoming)

103. D Ereira, "UK Restructuring and Insolvency Law: Current and Future Trends" (2010) April Practical Law Publishing Limited 23-29.

104. Part I of the Insolvency Act 1986 c. 45.

105. Section 895 of the Companies Act 2006 c. 46 106. C. 24

107. The Small Business, Enterprise and Employment Act 2015, c. 26.

108. The Deregulation Act 2015, c. 20. 
the deregulatory emphasis espoused by the current Conservative government and their overall focus on increasing freedom within the economy by reducing legislative restrictions. It follows that the employment protection regime in the UK does not provide a high level of protection that can be depended upon in insolvency situations.

The UK has recently undertaken to comply only minimally with EU obligations for worker protection going forward and will be seeking to renegotiate its membership in the EU in the near future, a process that will no doubt seek to curtail the interference the EU has had in UK policy matters. Conditions governing economic dismissals have been softened and thresholds loosened in order to increase labour market flexibility, making it easier for businesses to lay off workers. ${ }^{109}$ In particular, it has reduced the consultation period for collective dismissals from 90 to 45 days for redundancies of more than 100 employees and now excludes fixed term contracts that have reached their agreed termination date from collective redundancy obligations. ${ }^{110}$ There have also been reduced protections under the transfer of undertakings regulations: contractual conditions can now be more easily altered; dismissals are no longer automatically unfair for changes in workplace; collective agreements can be renegotiated a year after the transfer; and it is now more difficult to satisfy the criteria of a service provision change. ${ }^{111}$ While transfer of undertakings rules will not apply to transfers occurring with a view to liquidation, they will be implicated in most corporate rescue procedures.

Employees in the UK do, however, retain a status of preferential creditors. Unpaid wages and accrued holiday pay are given preferential priority in a distribution in advance of unsecured claims out of the assets of the company, although such claims are limited in amount. ${ }^{112}$ Employees are also able to claim against the state National Insurance Fund in respect of a number of limited unpaid debts associated with their employment. Unpaid employee pension contributions are also preferential for up to four months. Unpaid employer pension contributions are also preferential, but limited. ${ }^{113}$

\section{Greece}

Greece took steps in line with the protective function of labour law during the initial stages of the crisis; however, its approach changed completely ene its MoU eame inte-effect. ${ }^{114}$ The austerity measures imposed the MoU have had a severe impact on its welfare system. ${ }^{115}$ The overall goals of the MoU were to

109. M Magone, "Portugal" (2009) 48 Eur f Pol Res 1080, 1081.

110. B Hepple (n98) 203, 207-208.

111. ACAS " 2014 Changes to TUPE" (2014) Ref AL20 available from http://www.acas.org.uk/media/ pdf/1/1/9908-2901767-TSO-ACAS-

TUPE_is_changing-ACCESSIBLE.pdf first accessed 26 September 2014.

112. This is limited to an individual maximum of $£ 800$ as set out in Schedule 6 to the Insolvency Act 1986.
113. PM Secunda (n73) 867, 995-997.

114. C Papadimitriou, "The Greek Labour Law Face to the Crisis: A Dangerous Passage Towards a New Juridical Nature" (2013) European Labour Law Network - Working Paper Series, ELLN Working Paper 3/ 20134.

115. C Dimoulas, "Exploring the Impact of Employment Policy Measures in the Context of Crisis: The Case of Greece" (2014) Volume 67 Issue 2 International Social Security Review 49-65, 49-55. 
eliminate fiscal imbalances by achieving fiscal surpluses; to improve competitiveness; and to improve liquidity for Greece until its return to the financial markets. ${ }^{116}$ In order to do this, it was expected that wages would be lowered. ${ }^{117}$ The structural reforms to labour law were undertaken on the premise that labour market regulation constituted a significant barrier to growth. Prior to the crisis, there had been significant resistance to any flexibilisation of the labour market. By the time of the crisis, Greece had some of the strictest employment protection legislation in the EU. ${ }^{118}$ In counterpoint to Greece's previously extremely employee friendly policies, the austerity policies applied under its MoU are among the most severe fiscal austerity packages in Europe since the end of the Second World War. ${ }^{119}$ Employment remains highly fragile in those economies that have been subject to austerity measures and where business restructuring and its effect on job security is an ongoing reality. ${ }^{120}$

Following the introduction of austerity measures in Greece, significant changes were made to reduce the costs of hiring and firing employees. ${ }^{121}$ Greek law does not require the employer to justify the dismissal of an employee as a potentially fair reason, although this was mitigated prior to the crisis with generous severance packages, rendering the labour system practically inflexible. Following the crisis, notification periods were significantly reduced, thereby reducing the potential for severance compensation, and therefore the cost of dismissal. ${ }^{122}$ While justified in the name of competitiveness, these changes also promote the adoption of a short term solution for reducing costs via dismissals, rather than pursuing longer term strategies, undermining employment security. ${ }^{123}$ These changes have also made it easier to reduce the workforce in times of insolvency or restructuring.

Prior to the reforms of 2007, ${ }^{124}$ however, Greece lacked any kind of sophisticated corporate rescue regime. Rather, its insolvency system was geared toward liquidation historically resembling the French insolvency system. The new law aimed to update an outdated system by introducing radical changes to the Greek insolvency philosophy, providing for the rescue of ailing companies and offering a second chance to insolvent debtors. However, the procedures introduced were not adequate because of their consensual aspect, which was difficult because of a tradition of distrust in bankruptcy, a lack of cram-down in the agreements between debtor and creditors that made agreement difficult, and its lengthy

116. S Zartaloudis, "The Impact of the Fiscal Crisis on Greek and Portuguese Welfare States: Retrenchment before the Catch-up?" (2014) Volume 48 Issue 4 Social Policy and Administration 430-449, 438.

117. G Papadimitriou (n110) 8.

118. A Koukiadaki and L Krestos, "Opening Pandora's Box: The Sovereign Debt Crisis and Labour Market Regulation in Greece" (2012) 41(3) ILf 276, 278-280. 119. C Hadjmichalis, "Uneven Geographical Development and Socio Spatial Justice and Solidarity: European Regions after the 2009 Financial Crisis" (2011) 18 European Urban and Regional Studies 268.
120. A Muller, "Employment Protection Legislation Tested by the Economic Crisis: A Global Review of the Regulation of Collective dismissals for Economic Reasons" (2011) International Labour Office, Dialogue in Brief No. 3.

121. C Dimoulas (n111) 56.

122. C Papadimitriou (n110) 9.

123. A Koukiadaki and L Krestos, "Opening Pandora's Box: The Sovereign Debt Crisis and Labour Market Regulation in Greece" (2012) 41(3) ILf 286-287.

124. Law 3588/2007 enacted on 10 July 2007. 
administrative process. In addition, procedures were often abused by debtors as a means of securing a moratorium. ${ }^{125}$ In 2011 , a new law was passed which introduced a cram-down and a pre-bankruptcy procedure for companies in a state of financial weakness. A moratorium can also be put into place through a preliminary order by the court after an application for rehabilitation proceedings has been received. $^{126}$

While the new procedures were a clear improvement, they also have serious obstacles to overcome in order for it to make any significant contribution to rescuing companies, saving jobs and maximising value for the financially distressed debtor company's stakeholders overall. Access to the procedure is restricted to companies just on the verge of insolvency and that have perhaps already gone too far down the river to be rescued. The process is also still overly dependent on the Greek judicial system. While a pre-pack style of procedure is available in Greece, it required a number of months and contested hearings under Greek procedural requirements. Greek business culture is also an issue given that the success of a rescue proceeding depends on a residual trust and good faith among the debtor and its stakeholders. Greek business culture tends to be suspicious of these processes, viewing them as a prelude to default and often precipitating damaging responses from suppliers and banks. The abuse of the previous system does not help in this negative view. ${ }^{127}$

In terms of employee entitlements in insolvency, employee claims rank third in preference. Greek employees can also access a Fund for the Protection of Employees from Employer's Non-Reliability for the protection of wage claims not covered by their employers. Transfer of undertakings legislation, however, does not apply to those transfers occurring out of insolvency procedures with a view to liquidation, although they will likely apply in business transfers in the context of corporate rescue. Rules on collective redundancies were amended by a law of 2010 that raised the collective dismissals from four to six employees dismissed in enterprises with more than 20 employees and from 2 to $5 \%$ of employees in enterprises employing more than 150 people. ${ }^{128}$ It should be noted that this is still far more protective than the minimum requirements in the Collective Redundancies Directive. ${ }^{129}$ Thus, despite the changes applied to its collective redundancy regime, Greece remains highly protective in those circumstances relative to other EU Member States, ${ }^{130}$ although the new bail-out agreement approved in July 2015 by the Greek Parliament with the country's sovereign creditors may see additional reductions in Greece's socially protective stance. However, given the internal turmoil that is ongoing in this autumn of 2015, it is unclear what will happen with Greece's position in the Eurozone in the months to come.

125. S. Potamitis and A Rokas, "A New Pre-Bankruptcy Procedure for Greece" (2012) 3 fBL 235-247, 235-237.

126. Ibid., 237-241.

127. Ibid., 246-247.

128. A Muller (n1 16) 4; C Dimoulas (n111) 54; and A

Koukiadaki and L Krestos (n1 19) 287.
129. Directive 98/59/CE of 1998 on the approximation of the laws of the Member States relating to collective redundancies, OJ L 225/16. 130. G Dimoulas (n111) 54. 


\section{Portugal}

Prior to its bail-out, Portugal had the most rigid employment protection laws in the EU. ${ }^{131}$ Among developed nations it ranked last in terms of labour freedom ${ }^{132}$ and it has been asserted that such rigidity has impaired firm performance. ${ }^{133}$ While joining the Euro did have the effect of impairing Portugal's ability to provide cheap products to the European market because of the levelling effect of the common currency, its highly rigid and protective labour system were also at the root of Portugal's competitiveness problem, but this is also an inherently political issue. ${ }^{134}$ As early as 2005 , austerity measures had been enacted to combat an impending financial crisis that had been threatening since joining the EMU. ${ }^{135}$ Additional emergency austerity measures were introduced at various stages as a result of continued market pressure until Portugal was also forced to resort to the troika for assistance, agreeing to its own $\mathrm{MoU}$ and implementing cuts that went well beyond those suggested therein. ${ }^{136}$

The MoU specifically targeted several areas in need of labour reform: reduction of long term unemployment and strengthening social protections; reform of the employment protection legislation in order to combat the segmentation of the labour market and to facilitate the movement of workers between professions, markets and sectors; improve flexibility of working time rules in order to fit the needs of peak business times and thus augment the competitiveness of Portuguese businesses; to connect the costs of labour with effective job creation; and to approve legislation that serves to augment the employability of youth and of other traditionally disadvantaged categories of workers. ${ }^{137}$ A new labour code entered into force on 1 August 2012 that attempted to integrate the changes required in the $\mathrm{MoU}$, against a flurry of cries disputing the constitutionality of the reforms, which were summarily ignored by the government in power. ${ }^{138}$

Prior to the reforms to the Portuguese labour code, the Portuguese Constitution prohibited dismissals without a just cause. It was practically impossible to dismiss an employee who had not behaved in an illicit or deviant manner having such gravity that it effectively destroyed the employment relationship. ${ }^{139}$ Following the introduction of the new labour code in 2012, there has been an extension in the concepts of unsuitability and the extinction of worker positions in order to make individual dismissals easier. An employer can now establish non-discriminatory criteria for dismissals, drawing Portugal's redundancy rules in line with what

131. G Bragues, "Portugal's Plight: The Role of Social Democracy" (2012) 16(3) The Independent Rev 325, 338-339. 132. JA Vasconcellos, Portuguese Institute for Economic Freedom < http://institutoliberdadeeconomica.blogspot.co. uk/> accessed 24 September 2014.

133. PS Martins, "Dismissals for Cause: The Differences that just Eight Paragraphs can Make" (2009) 27 J Labour Economics 257.

134. G Bragues (n127) 339.

135. S Zartaloudis (n1 12) 437-443.

136. Ibid., 437-443.

137. AP Nascimento, "RELACIONES LABORALES Y REGULACIÓN DE LOS SISTEMAS DE
PREVISIÓN SOGIAL: A Reforma Laboral em Portugal" (2012) Actualidad Jurídica Uría Menéndez. Especial reformas estructurales, 47-61 <http://www.uria. com/documentos/publicaciones/3603/documento/ a5.pdf?id=4410 $>$ accessed 15 August 2014, 48.

138. "Controversial New Labour Code Comes into Force" European Industrial Relations Observatory Online, <http://www.eurofound.europa.eu/eiro/2012/ 05/articles/pt1205019i.htm> accessed 26 September 2014.

139. AP Nascimento (n133) 50. 
currently exists in the UK. Employers are also no longer obliged to offer a transfer to another suitable position when dismissing an employee for either unsuitability or the extinction of his job. ${ }^{140}$

The MoU also recommended changes to the Portuguese insolvency procedure, which was based in the German Insolvenzplan which was available only if the company was insolvent. ${ }^{141}$ Portuguese legislators introduced reforms in 2012 that added a new hybrid proceeding to the insolvency plan aimed only at pre-insolvency situations available to those companies facing economic difficulties or in an imminent insolvency situation. ${ }^{142}$ Since its implementation, the new revitalisation procedure has seemed popular among a number of different debtors. ${ }^{143}$ There are, however, certain weaknesses in this new procedure. While it is advantageous that the restructuring can now be carried out without the company being declared insolvent, in the event that negotiations do not arrive at an equitable solution, the company then risks being declared insolvent and submitted to the opening of proceedings. ${ }^{144}$ Part of the problem here is a cultural suspicion of debt and insolvency. If the debtor is unable to satisfy the creditors that any compromises made will be worth it, those creditors might well initiate insolvency proceedings in order to protect themselves from what they may view as an untenable or even unscrupulous process. ${ }^{145}$

Prior to reforms, the system governing collective redundancies in Portugal was rigid, requiring verification of the reasons for the dismissals and strict formal procedures. ${ }^{146}$ More flexible redundancy legislation has been introduced affecting the costs of lay-offs and other measures to reduce the financial burden on undertakings. Eligibility and qualification periods have been amended, providing more scope for worker dismissal, and redundancy benefits have been reduced. In addition, Portugal has introduced an "employers' compensation fund" to finance redundancy benefits. ${ }^{147}$ Wage claims in Portugal also receive priority under the Portuguese Bankruptcy Code and certain guarantees regarding various labour payments in insolvency. ${ }^{148}$ The Portuguese transfer of undertakings legislation will also apply to all transfers, including those occurring in the context of insolvency or rescue.

\section{E. Conclusion: convergence or natural selection?}

This treatise has attempted to showcase the effects of the financial crisis in the US and the EU, with a particular focus on Germany, France, the UK, Greece and

140. "Controversial New Labour Code Comes into Force" European Industrial Relations Observatory Online, <http://www.eurofound.europa.eu/eiro/ 2012/05/articles/pt1205019i.htm > accessed 26 September 2014.

141. AP Matos Martinas and MJ Andrade Campos, "Portugal" Chapter 3 in C Mallon (ed), The Restructuring Review (Law Business Research Ltd 2010) 276-277.

142. C Serra, "The Rescue of Large CorporationsHow Suitable is the Portuguese Insolvency Act?" (2013) in R Parry (dd.), Papers from the INSOL Europe Academic Forum / Nottingham Law School Foint International
Insolvency Conference, Nottingham Trent University, Nottingham, United Kingdom, 28 \& 29 June 2012, 2013, 97-99. 143. Ibid., 24-25.

144. Ibid., 97-99.

145. C Serra, "Country Reports: Portugal - the New Portuguese Insolvency Act" (2012) 47 EuroFenix - The Journal of INSOL Europe 40.

146. AP Nascimento (n133) 50.

147. S Clauwaert and I Schomann, "The Crisis and National Labour Law Reforms" (2012) Working Paper 2012.04 European Trade Union Institute 12-13.

148. PM Secunda (n73) 983-984. 
Portugal as examples of Member States diversely affected and responding to it and whether this has shown any elements of convergence. An examination of country specific responses and whether legislative reform in social policy and corporate rescue formed a part of that response demonstrates how a Member State's socio-political perspective, traditional values and regulatory style influence legislative responses. It is interesting to note as well that individual US states were also diversely affected by the financial crisis, but that they were unified under a single fiscal policy that restricted any opportunity for individual responses. EU Member States, however, are not bound by a single fiscal policy that allows direct interference with Member State economies, despite the unification under the EMU. As evidence suggests that the US is recovering more quickly than the $\mathrm{EU}$, and that the UK is recovering faster than the EMU, it could be surmised that the inability of the EU to make direct changes in fiscal policies of Member States because of its character as a loose constitutional federation with extremely diffuse power, may play a part in the EU's slow recovery and pending stagnation. The nature of the EU precludes any increase in direct interference, however. So perhaps the problem lies with the institutional structure itself.

The scope given to Member States in the implementation of social policy directives and the way in which they have been implemented demonstrate the differences in individual Member State systems of labour and employment law. There are strong path dependencies in labour law, which is true for individual Member States and even individual states of America. These culturally and traditionally grounded ideologies may hold lawmakers back from a uniform labour code on an EU or US Federal level. Changes in the differences in worker protection are often motivated by political events, such as the responses to the financial crisis in both the US and the EU. In the US, worker protection remains a domestic issue because of its federal structure and generally libertarian political ideology. ${ }^{149}$

Because of the MoUs in some Member States, the wish to avoid MoUs in others, and the perception that austerity is the only way to achieve recovery, a belief that has been summarily rebutted on several occasions by well known economists, there have indeed been signs of convergence toward a lowest common denominator in the EU; the UK. Corporate rescue is also steadily converging toward an EU wide rescue culture, although the ways and means that this is being achieved differ. the fundamental differences between social and economic policies and the legislation to which they relate, it is evident that economic issues have far greater cross-border implications. So perhaps a legal natural selection is taking place in corporate rescue regimes, while social policy, without any significant cross-border element, remains inextricably bound up with tradition and the socio-economic character of individual Member States.

While the power of the US Federal Government to legislate with regard to bankruptcy law forms a part of the very first Article of the Constitution, any federal intervention in labour or employment have had to find their justification in clauses

149. M Siems (n26) 10.

Copyright (C) 2015 INSOL International and John Wiley \& Sons, Ltd

Int. Insolv. Rev. (2015) DOI: $10.1002 /$ iir 
and amendments that may or may not provide enough muster to pass Supreme Court analysis. This seems directly opposed to the way in which insolvency and social policy are regulated within the EU. The European Insolvency Regulation only goes so far as to regulate in matters of cross-border insolvencies, while the social chapter has given the EU wide powers to legislate in matters of employment and labour regulation. While true that there the EU Commission has issued a recommendation introducing a new approach to business failure and insolvency that shifts the focus from liquidation to encouraging the early restructuring of viable businesses, ${ }^{150}$ this is merely exhortation and an invitation to reform, non-binding on the Member States. However, in areas of social policy, EU influence is far more heavily felt, despite the fact that legislation is only in the form of Directives, which are binding only to the achievement of the intended results.

While rule of law and historic documents such as the US Constitution and the EU Treaties are vital to the structure and integrity of the US and EU respectively, these are also man-made documents, written during a certain period of time under a certain set of circumstances. Time, circumstances and progress change. Why should the documents and rules that jurisdictions adhere to not also be adjustable in order to cope with the demands of the modern global marketplace and culture? Since the 1950s the EU has frequently revised and renewed the rules that provide for its governance and interaction with the Member States. The Constitution has retained the perception of inviolability and is viewed by many as a kind of holy writ that should not be interfered with under any circumstances, although twenty seven amendments disagree with that proposition. This treatise began on the premise that the EU might be able to learn something from the US; perhaps the learning curve could bend both ways.

150. See the Commission Recommendation of 12.03 .2014 on a new approach to business failure and insolvency 


\section{Author Query Form}

\section{Journal: International Insolvency Review}

\section{Article: iir_1246}

Dear Author,

During the copyediting of your paper, the following queries arose. Please respond to these by annotating your proofs with the necessary changes/additions.

- If you intend to annotate your proof electronically, please refer to the E-annotation guidelines.

- If you intend to annotate your proof by means of hard-copy mark-up, please use the standard proofing marks. If manually writing corrections on your proof and returning it by fax, do not write too close to the edge of the paper. Please remember that illegible mark-ups may delay publication.

Whether you opt for hard-copy or electronic annotation of your proofs, we recommend that you provide additional clarification of answers to queries by entering your answers on the query sheet, in addition to the text mark-up.

\begin{tabular}{|c|l|c|}
\hline Query No. & \multicolumn{1}{|c|}{ Query } & Remark \\
\hline Q1 & $\begin{array}{l}\text { AUTHOR: Please check suitability of suggested short } \\
\text { title. }\end{array}$ & \\
\hline
\end{tabular}


Required software to e-Annotate PDFs: Adobe Acrobat Professional or Adobe Reader (version 7.0 or above). (Note that this document uses screenshots from Adobe Reader $\mathrm{X}$ )

The latest version of Acrobat Reader can be downloaded for free at: http://get.adobe.com/uk/reader/

Once you have Acrobat Reader open on your computer, click on the Comment tab at the right of the toolbar:

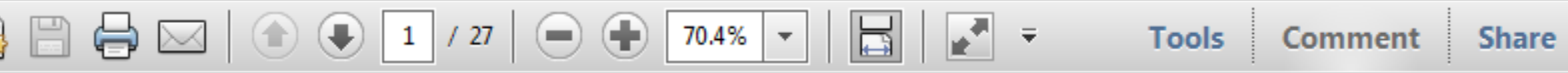

This will open up a panel down the right side of the document. The majority of tools you will use for annotating your proof will be in the Annotations section, pictured opposite. We've picked out some of these tools below:

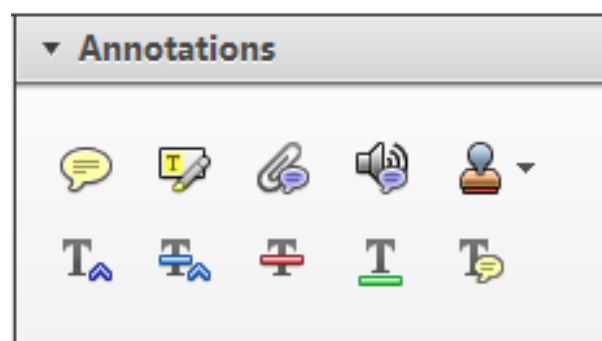

1. Replace (Ins) Tool - for replacing text.

Strikes a line through text and opens up a text box where replacement text can be entered.

How to use it

- Highlight a word or sentence.

- Click on the Replace (Ins) icon in the Annotations section.

- Type the replacement text into the blue box that appears.

Idard tramework for the analysis of $\mathrm{m}$ icy-Nevertheless, it also led to exog،

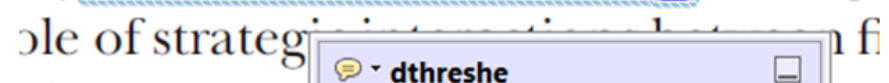
aber of comp 08/06/2011 15:58:17 is that the s1 nain compo: be level, are exc nc

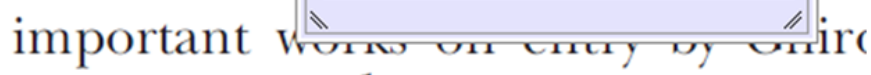
M heneferth) ${ }^{1}$ we anen the "hlarl $\mathrm{l}$

3. Add note to text Tool - for highlighting a section to be changed to bold or italic.

T Highlights text in yellow and opens up a text box where comments can be entered.

\section{How to use it}

- Highlight the relevant section of text.

- Click on the Add note to text icon in the Annotations section.

- Type instruction on what should be changed regarding the text into the yellow box that appears.

namic responses of mark ups ent with the VAR evidence

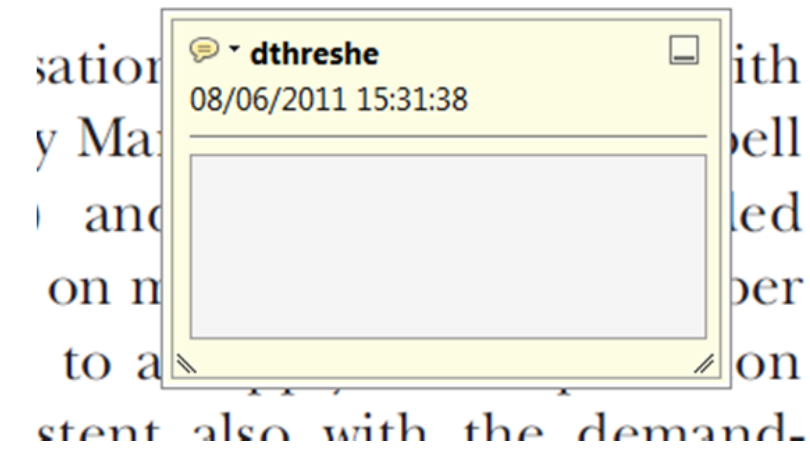

2. Strikethrough (Del) Tool - for deleting text.

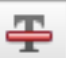

Strikes a red line through text that is to be deleted.

How to use it

- Highlight a word or sentence.

- Click on the Strikethrough (Del) icon in the Annotations section.

there is no room tor extra prohts al c ups are zero and the number of ret) values are not determined by Blanchard and Kiyotaki (1987), sfect competition in general equilil ts of aggregate demand and supply lassical framework assuming monol eph on evorenous number of firme

4. Add sticky note Tool - for making notes at specific points in the text.

Marks a point in the proof where a comment needs to be highlighted.

How to use it

- Click on the Add sticky note icon in the Annotations section.

- Click at the point in the proof where the comment should be inserted.

- Type the comment into the yellow box that appears.

iaisu airu suppiy sirucks. hivsl ui

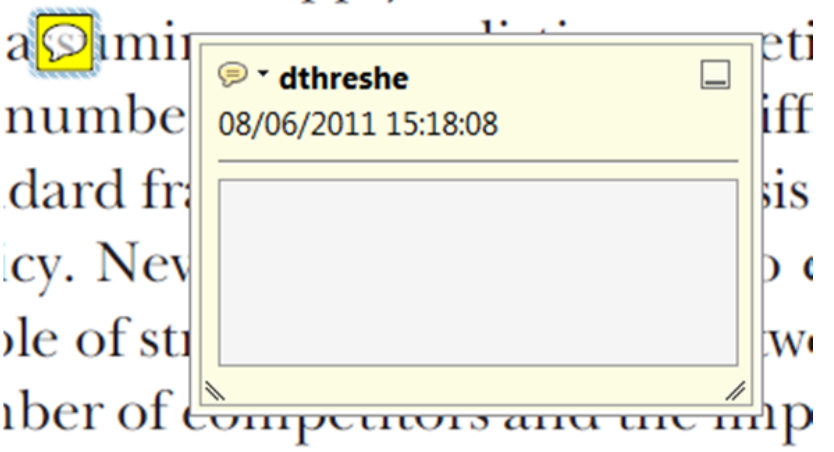

is that the structure of the secto. 
5. Attach File Tool - for inserting large amounts of text or replacement figures.

Inserts an icon linking to the attached file in the appropriate pace in the text.

How to use it

- Click on the Attach File icon in the Annotations section.

- Click on the proof to where you'd like the attached file to be linked.

- Select the file to be attached from your computer or network.

- Select the colour and type of icon that will appear in the proof. Click OK.

E N D

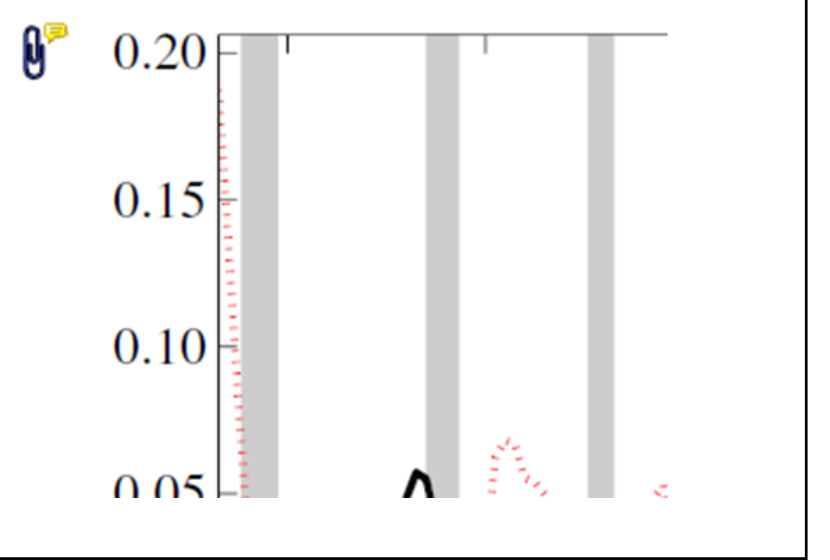

6. Add stamp Tool - for approving a proof if no corrections are required.

- Inserts a selected stamp onto an appropriate place in the proof.

\section{How to use it}

- Click on the Add stamp icon in the Annotations section.

- $\quad$ Select the stamp you want to use. (The Approved stamp is usually available directly in the menu that appears).

- Click on the proof where you'd like the stamp to appear. (Where a proof is to be approved as it is, this would normally be on the first page).

or the business cycie, starting with the on perfect competition, constant ret

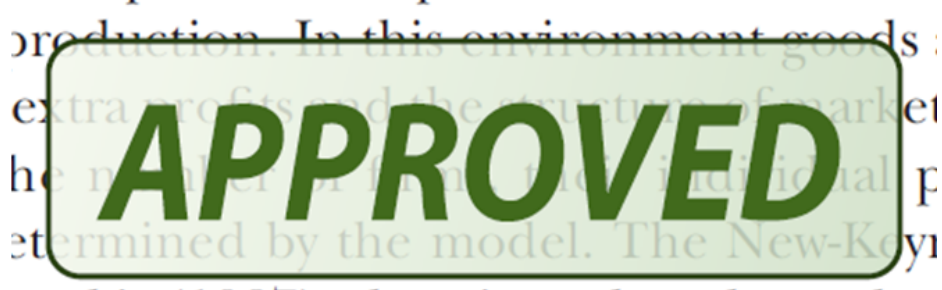
otaki (1987), has introduced produc general equilibrium models with nomin:

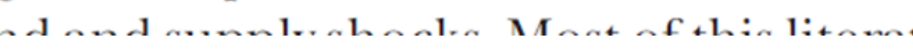

- Drawing Markups

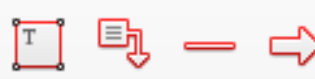

$0 \bigcirc \sqrt{6} \otimes$

\section{How to use it}

- Click on one of the shapes in the Drawing Markups section.

- Click on the proof at the relevant point and draw the selected shape with the cursor.

- To add a comment to the drawn shape, move the cursor over the shape until an arrowhead appears.

- Double click on the shape and type any text in the red box that appears.
7. Drawing Markups Tools - for drawing shapes, lines and freeform annotations on proofs and commenting on these marks.

Allows shapes, lines and freeform annotations to be drawn on proofs and for comment to be made on these marks.

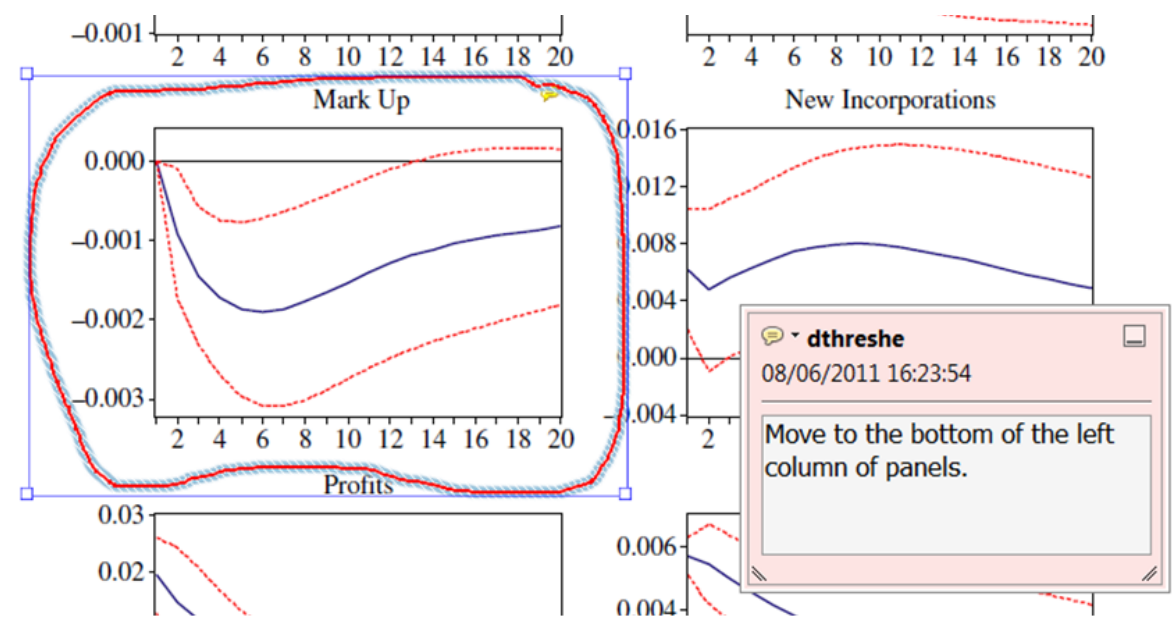

For further information on how to annotate proofs, click on the Help menu to reveal a list of further options:

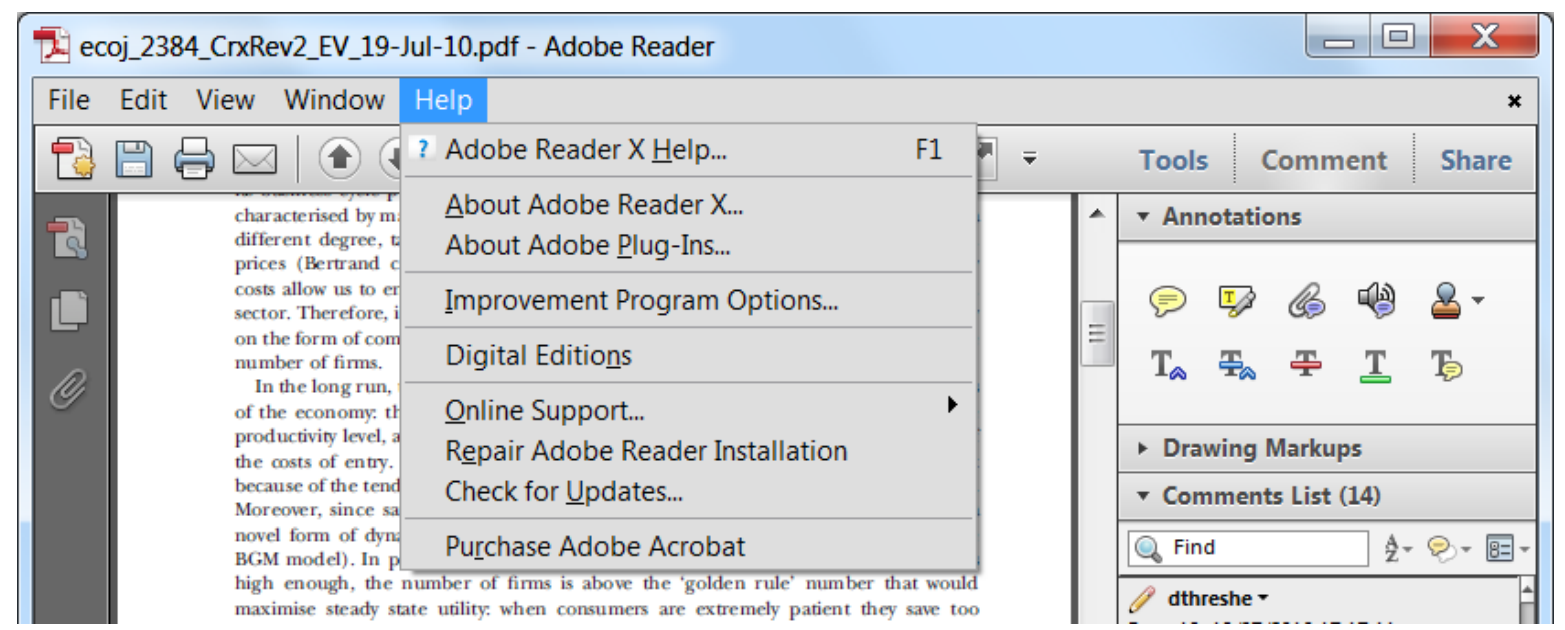

